\title{
DETECTION OF CRYPTOSPORIDIUM SPP. OOCYSTS IN RAW SEWAGE AND CREEK WATER IN THE CITY OF SÃO PAULO, BRAZIL
}

\author{
Eveline Wilma Coutinho Farias; Rosa C. Gamba; Vivian Helena Pellizari*
}

Instituto de Ciências Biomédicas, Departamento de Microbiologia, Universidade de São Paulo, São Paulo, SP, Brasil

Submitted: May 15, 2001; Returned to authors for corrections: July 05, 2001; Approved: February 25, 2002

\begin{abstract}
The protozoan parasite Cryptosporidium has emerged as one of the most important contaminants of water, causing waterborne outbreaks of gastroenteritis worldwide. To monitor and understand the public health significance of this pathogen in environmental samples, several methods have been developed to isolate and detect Cryptosporidium oocysts. The purpose of this study was to perform the first investigation on the presence of Cryptosporidium spp. oocysts in raw sewage and creek water in the city of São Paulo, Brazil. The oocysts were concentrated by flocculation and membrane filtration. The results showed the occurrence of Cryptosporidium spp. in all wastewater samples analyzed, indicating a possible risk for dissemination of these pathogens in aquatic environment and in the community.
\end{abstract}

Key words: Cryptosporidium spp., sewage, creek waters

\section{INTRODUCTION}

The role of sewage-polluted waters in the transmission and outbreaks of microbial illness is well known. Substantial concern persists that pathogen occurrence in water supplies may be responsible for the transmission of background (endemic) levels of enteric disease $(2,9,10)$.

Many outbreaks of giardiasis and cryptosporidiosis have been reported in the last few decades and water has been considered one of the major routes of dissemination (5). Positive findings of oocysts in untreated wastewater, filtered secondarily treated wastewater, activated sludge effluent, combined sewer overflows, groundwater, surface water, and treated drinking water indicate widespread fecal contamination $(6,11)$.

Epidemiological evaluations on the contribution of polluted waters to cryptosporidiosis in endemic settings are not available, especially because there is no standardized technique to recover Cryptosporidium oocysts from environmental samples. Methods such as continuous flow centrifugation, membrane and cartridge filtration, calcium carbonate flocculation and polycarbonate membrane systems have been used to concentrate oocysts in water samples before they can be detected, but efforts to find a reliable, sensitive and practical method must be continuously pursued (3). Other considerations about current methods should be made, since these techniques could be too expensive to be adopted in developed and underdeveloped countries.

In Brazil, research about the occurrence and methods for detection of this pathogen in environmental samples is necessary, since few data are available. In addition, the new Brazilian Federal Legislation (law 1649 as of December 29 ${ }^{\text {th }}, 2000$ ) recommends the investigation for the presence of oocysts in water.

The purpose of this study was to perform the first investigation of the presence of Cryptosporidium spp. oocysts in raw sewage and creek waters in the city of São Paulo using two concentration methods: Calcium Carbonate Flocculation (12) and the Membrane-Filter Dissolution Method (1).

\section{MATERIALS AND METHODS}

From July to December 199824 samples of raw domestic sewage and sewage-polluted creek waters were collected at two sites in the city of São Paulo: the effluent of the Edu Chaves Sewage Pumping Station (SPS) and the creek Pirajussara. The

\footnotetext{
* Corresponding author. Mailing Address. Av. Prof. Lineu Prestes, 1374, Cidade Universitária, Departamento de Microbiologia, Instituto de Ciências Biomédicas, Universidade de São Paulo. 05508-900, São Paulo, SP, Brasil. E-mails: ewcfaria@usp.br/ vivianp@usp.br / rcgamba@usp.br
} 
samples were transported in ice to the laboratory in sterile 10liter plastic (high density polyethylene) containers.

Calcium Carbonate Flocculation was performed according to Vesey et al. (12). Briefly, $50 \mathrm{~mL}$ of $1 \mathrm{~mol} \mathrm{~L}^{-1} \mathrm{CaCl}_{2}$ and $50 \mathrm{~mL}$ of $1 \mathrm{~mol} \mathrm{~L}^{-1} \mathrm{NaHCO}_{3}$ were added to each container with samples of $5 \mathrm{~L}$. After further mixing, the $\mathrm{pH}$ was adjusted to 10 by the addition of $1 \mathrm{~mol} \mathrm{~L}^{-1} \mathrm{NaOH}$. The solutions were left at room temperature for 4 hours to allow the formed flocs to settle. The supernatant fluid was aspirated and discarded. Care was taken not to disturb the calcium carbonate residue. The flocs were dissolved by adding $100 \mathrm{~mL}$ of $10 \% \mathrm{w} / \mathrm{v}$ Sulphamic Acid, centrifuged in $250 \mathrm{~mL}$ centrifuge bottles at $3000 \mathrm{~g}$ for $15 \mathrm{~min}$ and the supernatant fluids discarded. The pellets were transferred to $50 \mathrm{~mL}$ centrifuge tubes and centrifuged at $3000 \mathrm{~g}$ for $15 \mathrm{~min}$. The supernatant fluids were decanted and the pellets combined and adjusted with elution fluid (1\% Tween 80, SDS, 1\%, PBS 10X, 0.001\% Antifoam A).

Membrane-Filter Dissolution Method was conducted according to Aldom and Chagla (1). The 2L samples were filtered through a $142 \mathrm{~mm}$-diameter, $1.2 \mu \mathrm{m}$-pore cellulose acetate membrane filters (Millipore). After filtration, the membrane were folded, transferred to $250 \mathrm{~mL}$ centrifuge bottles, and dissolved in $200 \mathrm{~mL}$ acetone. The dissolved membrane was successively centrifuged at $650 \mathrm{~g}$ for $15 \mathrm{~min}$ and resuspended in acetone, 95\% ethanol, $70 \%$ ethanol and elution fluid.

The final concentrated samples obtained by both methods were suspended in $10 \mathrm{~mL}$ elution fluid and a $10 \mu \mathrm{L}$ sample was transferred to wells of the microscope slide provided in the Merifluor Cryptosporidium, Giardia Kit (Meridian Diagnostics, Cincinnati, $\mathrm{OH})$. The slides were stained according to the manufacturer's instructions. The oocysts in each well were counted with an epifluorescence microscope (DAS Leica DM LB / Germany) at 400X magnification and confirmed by phase contrast.

The number of oocysts detected per liter was calculated by the average of the counting of three slides: (1) number of oocysts in an analyzed drop $\mathrm{x}$ total $\mathrm{mL}$ of the pellet / volume of analyzed drop = number of oocysts in pellet; (2) number of oocysts in pellet $/$ number of liters filtered or flocculated $=$ number of oocysts $/ \mathrm{L}$.

A statistical analysis using t-student test (95\% confidence level) was performed. The analysis was carried out for the data obtained by the two concentration methods.

Negative (distilled water) and positive (Cryptosporidium oocysts) control samples were also used throughout the study.

\section{RESULTS AND DISCUSSION}

In Brazil, about 30 million people have no access to treated drinking water and only a limited segment of the population in the large cities has access to urban sewage system, otherwise sewage is discharged into creeks and rivers (7). Therefore, high risk of waterborne cryptosporidiosis has to be taken into consideration.

In this study, oocysts of Cryptosporidium spp. were detected in all 24 wastewater samples collected in the city of São Paulo.
The actual number of oocysts/L was calculated as the average counts obtained by the two methods employed to concentrate oocysts. Raw sewage samples yielded $80-912$ oocysts/L while in creek waters, oocysts numbers varied from 65 to 760/L (Fig. 1).

We also noted that oocysts numbers were usually higher in the Pirajussara Creek than in the domestic effluent of Edu Chaves SPS, showing the fecal contamination of these surface waters.

Moreover, these waters circulate in the metropolitan area and must be affecting the quality of local water supplies, since the presence of Cryptosporidium oocysts was determined in this city's groundwater (4), raw and treated water (8), drawing an apparent potential to cryptosporidiosis outbreak.

On the other hand, a number of considerations must be taken into account in the interpretation and significance of the obtained data. These are directly related to the sensitivity of the methods used to recover and detect Cryptosporidium oocysts from environmental samples.

In this study, for example, no statistically significant difference was observed between concentration methods using filtration or carbonate flocculation for detection of Cryptosporidium oocysts $(\mathrm{P}<0.05)$ (Table 1). However, the high concentration of suspended solids in the analyzed samples may be affecting the interpretation of results.

A major problem with the method of concentrating oocysts by filtration, besides its high cost, is the compaction of particles on and around the oocysts. This compaction occurs during filtration and the oocysts that are attached to other particles are incorporated into aggregates and may be missed during the detection stage. Disaggregation of these compacted particles is difficult and oocysts will be lost if a density gradient centrifugation procedure is used to clarify the sample.

The flocculation procedure described by Vesey et al. (12) has been reported as a more simple and gentle method. Oocysts are

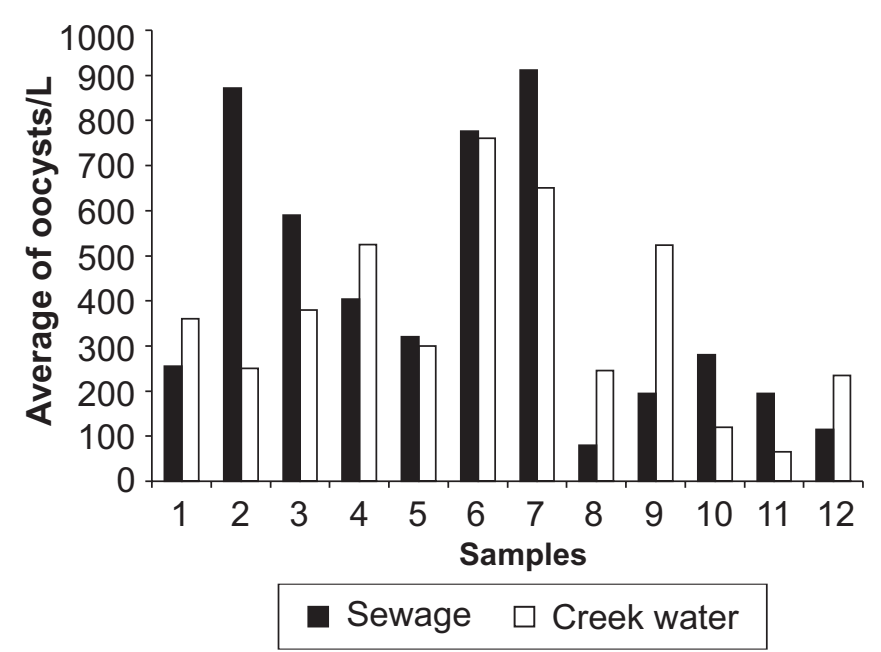

Figure 1. Levels of oocysts/L detected in raw sewage and creek waters in the city of São Paulo. 
Table 1. Detection of Cryptosporidium spp. oocysts in raw sewage and creek water, concentrating $2 \mathrm{~L}$ by membrane filtration and $5 \mathrm{~L}$ by calcium carbonate flocculation.

\begin{tabular}{ccccc}
\hline & \multicolumn{4}{c}{ Number of oocysts/L } \\
Samples & Raw sewage & \multicolumn{2}{c}{ Creek Water } \\
\cline { 2 - 5 } & Filtration & $\begin{array}{c}\text { Carbonate } \\
\text { flocculation }\end{array}$ & Filtration & $\begin{array}{c}\text { Carbonate } \\
\text { flocculation }\end{array}$ \\
\hline 1 & 150 & 360 & 480 & 240 \\
2 & 1200 & 544 & 300 & 200 \\
3 & 500 & 680 & 600 & 160 \\
4 & 280 & 528 & 150 & 900 \\
5 & 200 & 440 & 300 & 300 \\
6 & 1200 & 352 & 1400 & 120 \\
7 & 1200 & 624 & 1000 & 300 \\
8 & 160 & 0 & 150 & 340 \\
9 & 150 & 240 & 1000 & 48 \\
10 & 500 & 60 & 0 & 240 \\
11 & 50 & 340 & 50 & 80 \\
12 & 150 & 80 & 150 & 320 \\
\hline Average* & 478,333 & 354 & 465 & 270,666 \\
\hline P-value & \multicolumn{5}{c}{0.4058} & \multicolumn{3}{c}{0.1909} \\
\hline
\end{tabular}

* No statistically significant differences were observed between the averages.

concentrated in a dense and stable residue at the bottom of a container within 4 hours and the residue can be rapidly dissolved in sulphamic acid. This procedure concentrates particles of a wide range of sizes, resulting in a residue which may contain a greater amount of particulate matter than when filtration methods are used. However, this particulate matter is less compacted and aggregated than the one obtained by filtration.

In fact, lower recoveries of the oocysts were attributed to high turbidity in those methods $(12,13)$, but the carbonate flocculation shows great promise to analyze samples with high concentrations of suspended solids. Further analysis might be required to improve the method and to determine its performance, before it can be routinely used.

\section{ACKNOWLEDGEMENTS}

The authors are thankful to Dolores Mehnert for helping in sampling and to the Brazilian Research Agency CAPES for supporting this research.

\section{RESUMO}

\section{Cryptosporidium spp. em águas de esgoto}

O protozoário Cryptosporidium é um importante patógeno contaminante de água, causador de surtos de gastroenterite em vários países. Na tentativa de compreender e monitorar o significado desse patógeno em amostras ambientais, vários métodos foram desenvolvidos para o isolamento e identificação de oocistos de Cryptosporidium. O objetivo deste trabalho foi realizar a primeira investigação da presença de oocistos de Cryptosporidium em águas de esgoto e de córrego no município de São Paulo. Os oocistos foram concentrados por floculação e por filtração em membrana. Os resultados indicaram a ocorrência de Cryptosporidium em todas as amostras analisadas, indicando um potencial risco de disseminação desse patógeno no ambiente aquático e também na comunidade.

Palavras-chave: Cryptosporidium spp., águas de esgoto, águas de córrego

\section{REFERENCES}

1. Aldom, J.E.; Chagla, A.H. Recovery of Cryptosporidium oocysts from water by a membrane filter dissolution method. Lett. Appl. Microbiol., 20: 186-7, 1995.

2. EPA- Environmental Protection Agency. National primary drinking water regulations: enhanced surface drinking water treatment requirements; proposed rule. (Code of Federal regulations, volume 40: protection of environment. Parts 141 and 142), 1994 Washington, DC: Office of the Federal Register, National Archives and Records Service.

3. Fayer, R.; Morgan, U.; Upton, S.J. Epidemiology of Cryptosporidium: transmission, detection and identification. Intern. J. Parasitol., 30: 1305-22, 2000.

4. Gamba, R.C.; Ciapina, E.M.P.; Espíndola, R.S.; Pacheco, A.; Pellizari, V.H. Detection of Cryptosporiudium sp. oocysts in groundwater for human consumption in Itaquaquecetuba city, S. Paulo- Brazil. Braz. J. Microbiol., 31: 151-153, 2000.

5. Hsu, B-M.; Huang, C.; Hsu, Y-F.; Jiang, G-Y.; Hsu, C.L. Evaluation of two concentration methods for detecting Giardia and Cryptosporidium in water. Wat Res., 35: 419-429.

6. Johnson, D.C.; Reynolds, K.A.; Gerba, C.P.; Pepper, I.L.; Rose, J.B., 1995. Detection of Giardia and Cryptosporidium in marine waters. Water Sci Technol., 31: 439-42, 2001.

7. Mehnert, D.U.; Stewien, K.E. Detection and distribution of rotavirus in raw sewage and creeks in São Paulo, Brazil. Appl. Environ Microbiol., 59: 140-143, 1993.

8. Muller. Detection of Cryptosporidium spp. in raw and drinking waters in São Paulo city. Master Graduate thesis. University of São Paulo, São Paulo, Br, 2000.

9. Payment, P.; Siemiatycki, J.; Richardson, L., et al. A prospective epidemiological study of gastrointestinal health effects due to the consumption of drinking water. Int. J. Environ. Health Res., 7: 5-31, 1997.

10. Perz, J.F.; Ennever, F.K.; La Blancq, S.M. Cryptosporidium in tap water. Amer. J. Epidemiol., 17: 289-301, 1998.

11. Rose, L.B.; Lisle, J.T.; LeChevallier, M. Waterborne cryptosporidiosis: incidence, outbreaks, and treatment strategies. In: Fayer, R. editor. Cryptosporidium and cryptosporidiosis. Boca Raton, FL: CRC Press. 1997, pp.93-110.

12. Vesey, G.; Slade, J.P.; Byrne, M.; Sheperd, K.; Fricker, C.R. A new method for the concentration of Cryptosporidium oocysts from water. J. Appl. Bacteriol., 75: 82-6, 1993.

13. Zuckerman, U.; Armon, R.; Tizipori, S.; Gold, D. Evaluation of a portable differential continuous flow centrifuge for concentration of Cryptosporidium oocysts and Giardia cysts from water. J. Appl. Microbiol., 86: 955-61, 1999. 